\author{
S.F. Pylypaka ${ }^{1}$, V.M. Nesvidomin ${ }^{1}$, M.B. Klendii ${ }^{2}$, \\ I.L. Rogovskii ${ }^{1}$, T.A. Kresan ${ }^{3}$, V.I. Trokhaniak ${ }^{1}$ \\ ${ }^{1}$ National University of Life and Environmental Sciences of Ukraine, Kiev, Ukraine; \\ ${ }^{2}$ Separated Subdivision of National University of Life and Environmental Sciences of Ukraine, \\ Berezhany Agrotechnical Institute, Ukraine; \\ ${ }^{3}$ Separated Subdivision of National University of Life and Environmental Sciences of Ukraine \\ Nizhyn Agrotechnical Institute, Ukraine \\ (E-mail: trohaniak.v@gmail.com)
}

\title{
Conveyance of a particle by a vertical screw, which is limited by a coaxial fixed cylinder
}

\begin{abstract}
Differential equations of relative particle motion along the periphery of a vertical screw have been deduced which rotates about its axis and is limited by a coaxial fixed cylinder. The equations have been solved by applying numerical methods and the trajectories of relative particle helical motion, that is to say, movement along the edge of a screw, which is common for a screw surface and for a limiting cylinder, have been built. The force of particle friction on the screw surface and on the surface of a cylindrical cover has been taken into consideration. The cases, when a helix angle, that is to say, the angle of screw edge inclination, is less than the angle of particle friction on the surface of a screw, when it is equal to a friction angle and when it is higher than a friction angle, have been considered. In addition, a specific case, when a screw is fixed and a particle moves downwards by gravity, which takes place in spiral chutes, has been analyzed. Kinematic characteristics-time curves have been presented.
\end{abstract}

Keywords: particle, vertical screw, angular velocity of rotation, cylindrical cover, differential equations, kinematic parameters.

\section{Introduction}

A screw surface is a universal structural element of various machines. The surface of a screw conoid, which is referred to as a screw, is the most common one. It is widely used in screw conveyers for transporting technological material. A separate element of the material is a body, movement on a running surface of which is very difficult to describe, because, in this case, the inertia forces that arise from its rotation must be taken into account. In some cases, these forces can be neglected or they can be ignored, if the size of a body is small and it is taken as a material particle [1] or in case of low angular velocities of a body, for example, when handling machinery is operated [2]. It is essential to study the movement of material particles on the surface of a screw, which rotates about its axis. Paper [3] considers their movement on a vertical screw beginning from the axis of rotation to the point when they reach a limiting cylinder. The conveyance of particles upwards takes place after they collide with a limiting cylindrical cover. The paper investigates the movement of a particle when interacting with two surfaces: the surface of a running screw and the surface of a fixed cylindrical cover. The nature of material particles is rather broad. They include not only mechanical particles but fluid or gas particles, which interact with running surfaces, as well [4]. The movement of mechanical particles on the surface of a running soil tilling disk is considered in paper [5], its movement on the surface of a cylinder is covered in paper [6] and its motion on the surface of a cone is investigated in paper [7]. The study of the movement of particles on screw surfaces is of practical importance because such surfaces are used in screw conveyers [8, 9], in separators [10] and other in the papers [11-18].

\section{Material and method.}

In paper [4] it is stated that, if a particle moves by gravity on the surface of a fixed vertical screw conoid, it moves away from its axis. It happens because of the fact that a particle moves along a curvilinear trajectory, which results in the appearance of a centrifugal force that causes particle movement to the periphery. If a screw 
conoid rotates about its axis, a particle performs a compound motion: it slides on the surface of a conoid, but in absolute motion it rotates about the axis of a conoid as well, which causes particle movement to the periphery. Thus, it reaches a cylindrical cover. The common line of a conoid and a cover (that is to say, the line of their intersection) is a screw line. A particle slides along this screw line having simultaneous contact with the surface of a conoid (a screw) and with the surface of a cylindrical cover. Let us begin the development of the mathematical model of particle movement by writing the parametric equation of a helical line:

$$
x=R \cos \alpha ; \quad y=R \sin \alpha ; \quad z=-R \alpha \operatorname{tg} \beta,
$$

where $R$ - the radius of a limiting cylinder - a constant value; $\beta$ - the angle of a helix - a constant value; $\alpha$ - the rotation angle of the point of a helix about its axis - an independent variable.

Two surfaces pass through a helix (1): a screw conoid (a screw) and a cylinder. When a particle contacts these two surfaces, reaction forces appear, which are directed normally to them. In order to find the directions of these normal lines, it is necessary to have surface equations.

The surface of a screw is made up by the plural of rectilinear generators, which are parallel to a horizontal plane. Their one end passes through a helix (1) and their another end is directed to the axis of a screw (Fig. 1, a). Based on the screw principle, let us write its parametric equations:

$$
\begin{gathered}
X=(R-u) \cos \alpha ; \\
Y=(R-u) \sin \alpha ; \\
Z=-R \alpha \operatorname{tg} \beta,
\end{gathered}
$$

where $u$ - the length of a rectilinear generator of a screw - the second independent variable of the surface.

Counting the length of a generator begins from a helix. If $u=R-r$, where $r$ - the radius of a screw shaft, the surface will be limited by two helixes (Fig. 1, a). At $u=0$ the parametric equations of a helix are obtained (1). In order to differentiate surface equations from line equations, let us write them in lower case for a line and in upper case for a surface.

A vertical screw rotates about its axis with the angular velocity $\omega$. A particle is on a helix (1) and, at the same time, it contacts a moving part of a screw surface and a fixed surface of a cylindrical cover (Fig. 1, b). The following forces are exerted on it: weight force $m g\left(m-\right.$ the mass of a particle, $g=9.81 \mathrm{~m} / \mathrm{s}^{2}-$ the acceleration of gravity), the reaction $N$ of the conoid surface directed along the normal to its surface, the reaction $N_{R}$, directed along the normal to the surface of a cylinder and the reaction force $F_{f}$ (Fig. 1 , b). Suppose a particle moves upwards in absolute motion, then the friction force on a screw surface $F_{f a}$ is directed oppositely to the direction of sliding, and the one on a cylinder surface $F_{f c}$ - oppositely to the velocity of absolute motion (Fig. 1, b). The vectors of these forces will be tangential relative to the trajectory of relative motion (the helix, along which a particle is sliding) and absolute motion (the cylindrical line on the cover, which is not shown). They are non-collinear, but act in opposite directions.
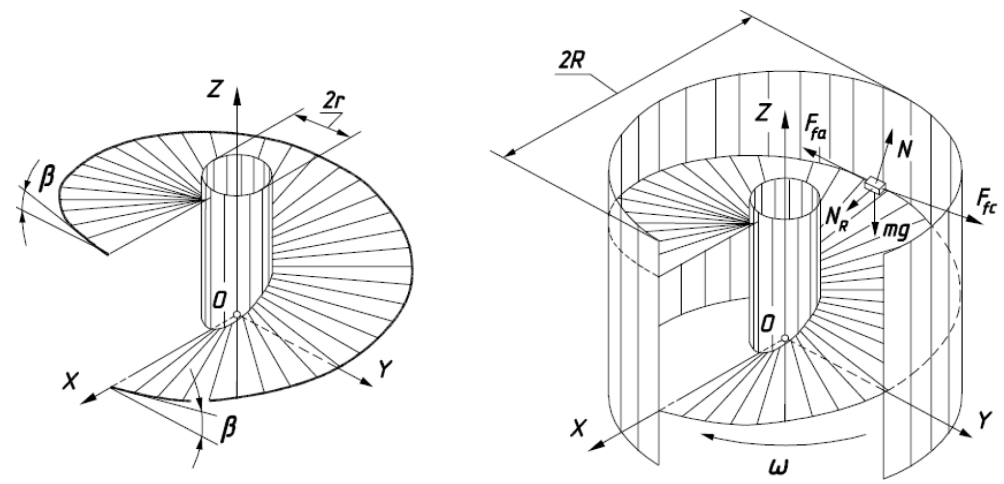

Figure 1. To the conveyance of a particle by a vertical screw:

a) one flight of a screw surface, limited by the outer edge - a helix with the inclination angle $\beta$;

b) the forces exerted upon a particle, with interacts with two surfaces: the one of a screw and the one of a cylindrical cover 
Let us derive a motion equation in the form of $m \bar{a}=\bar{F}$, where $m$-particle mass, $\bar{a}$ - the vector of absolute acceleration, $\bar{F}$ - the resultant vector of the exerted forces listed above. Let us write the vector equation in projections onto OXYZ coordinates.

If we assume the variable $\alpha$ to be time-dependent $t$ in the equations (1), that is to say, $\alpha=\alpha(t)$, this internal dependence will define the law of particle sliding along a helix, that is to say, the law of relative motion. Thus, under this condition, the equations (1) are the equations of relative motion.

A screw rotates about its axis with the angular velocity $\omega$. During the time $t$ it rotates by the angle $\alpha_{a}=-\omega t$ and moves along a helix for a certain distance, according to the equations (1). The direction of screw rotation is chosen so that a particle can move upwards in absolute motion, when it slides along a helix. Let us rotate the helix (1) about $\mathrm{OZ}$ axis by the angle $\alpha_{a}=-\omega t$, according to the known rotation equations:

$$
\begin{gathered}
x_{a}=R \cos \alpha \cos (-\omega t)-R \sin \alpha \sin (-\omega t)=R \cos (\omega t-\alpha) ; \\
y_{a}=R \cos \alpha \sin (-\omega t)+R \sin \alpha \cos (-\omega t)=-R \sin (\omega t-\alpha) ; \\
z_{a}=-R \alpha \operatorname{tg} \beta .
\end{gathered}
$$

The parametric equations (3) take into consideration two rotational motions: by the angle $\alpha=\alpha(t)$ in relative motion and by the angle $\alpha_{a}=-\omega t$ in translational motion, thus, they are the equations of absolute particle motion.

Let us differentiate the equations (3) with respect to the time $t$ and we obtain the projections of the absolute velocity vector:

$$
\begin{gathered}
x_{a}^{\prime}=-R\left(\omega-\alpha^{\prime}\right) \sin (\omega t-\alpha) \\
y_{a}^{\prime}=-R\left(\omega-\alpha^{\prime}\right) \cos (\omega t-\alpha) \\
z_{a}^{\prime}=-R \alpha^{\prime} \operatorname{tg} \beta
\end{gathered}
$$

Its value can be found as a geometric sum of the projections (4):

$$
V_{a}=\sqrt{x_{a}^{\prime 2}+y_{a}^{\prime 2}+z_{a}^{\prime 2}}=\frac{R}{\cos \beta} \sqrt{\omega\left(\omega-2 \alpha^{\prime}\right) \cos ^{2} \beta+\alpha^{\prime 2}} .
$$

Let us find the projections of the unit vector, which sets the direction of particle absolute velocity, by dividing the equations (4) by the velocity value (5):

$$
\begin{gathered}
T_{\text {Vax }}=-\frac{\left(\omega-\alpha^{\prime}\right) \sin (\omega t-\alpha) \cos \beta}{A} ; \\
T_{\text {Vay }}=-\frac{\left(\omega-\alpha^{\prime}\right) \cos (\omega t-\alpha) \cos \beta}{A}, \\
T_{V a z}=-\frac{\alpha^{\prime} \sin \beta}{A}
\end{gathered}
$$

where $A=\sqrt{\omega\left(\omega-2 \alpha^{\prime}\right) \cos ^{2} \beta+\alpha^{\prime 2}}$.

Having differentiated the equation (4), we obtain the projections of the absolute acceleration $w$ of a particle:

$$
\begin{gathered}
x_{a}^{\prime \prime}=R \alpha^{\prime \prime} \sin (\omega t-\alpha)-R\left(\omega-\alpha^{\prime}\right)^{2} \cos (\omega t-\alpha) ; \\
y_{a}^{\prime \prime}=R \alpha^{\prime \prime} \cos (\omega t-\alpha)+R\left(\omega-\alpha^{\prime}\right)^{2} \sin (\omega t-\alpha) ; \\
z_{a}^{\prime \prime}=-R \alpha^{\prime \prime} \operatorname{tg} \beta .
\end{gathered}
$$

In order to break the equation $m \bar{a}=\bar{F}$ in projections onto the axes of OXYZ coordinates, it is necessary to determine the directions of the forces, which are shown in Figure 1, b. In case of one of the forces - the friction force $F_{f c}$ - its direction is found in the form of a unit vector (6), here, it is worth taking into account that the action of the force $F_{f c}$ is directed oppositely to this vector. Let us find the direction of the friction force $F_{f a}$, which is directed oppositely to the vector of relative velocity. Let us find the projections of this vector by differentiating the equations (1):

$$
x^{\prime}=-R \alpha^{\prime} \sin \alpha
$$




$$
\begin{aligned}
& y^{\prime}=R \alpha^{\prime} \cos \alpha \\
& z^{\prime}=-R \alpha^{\prime} \operatorname{tg} \beta .
\end{aligned}
$$

Let us find the value of absolute particle motion:

$$
V=\sqrt{x^{2}+y^{\prime 2}+z^{\prime 2}}=\frac{R \alpha^{\prime}}{\cos \beta} .
$$

Let us find the projections of a unit directing vector of relative velocity by dividing the projections (8) of this velocity by its absolute value (9):

$$
T_{V x}=-\cos \beta \sin \alpha ; \quad T_{V y}=\cos \beta \cos \alpha ; \quad T_{V z}=-\sin \beta .
$$

The vector projections (10) are written without taking into consideration helix rotary motion. All the forces are projected onto fixed OXYZ coordinates. In order to exert the force $F_{f a}$ at the point of particle location, it is necessary to rotate the projections $(10)$ by the angle $(-\omega t)$ about $O z$ axis. Afterwards they take the following form:

$$
\{\cos \beta \sin (\omega t-\alpha) ; \quad \cos \beta \cos (\omega t-\alpha) ; \quad-\sin \beta\} .
$$

Let us find the direction of the reaction forces of a screw surface and of a cylindrical cover surface.

The direction of a normal to the surface is determined by a vector product of two vectors that pass through the point on the surface (the point where a particle is located) and the tangents to the coordinate lines, which pass through this point. Let us find a normal vector to the screw surface. The vectors, which are tangent to the coordinate lines of the surface, are partial derivatives of the equations (2) of a screw:

$$
\begin{array}{rlrl}
\frac{\partial X}{\partial \alpha} & =-(R-u) \sin \alpha ; & \frac{\partial X}{\partial u} & =-\cos \alpha ; \\
\frac{\partial Y}{\partial \alpha}=(R-u) \cos \alpha ; & \frac{\partial Y}{\partial u} & =-\sin \alpha ; \\
\frac{\partial Z}{\partial \alpha}=-R \operatorname{tg} \beta ; & \frac{\partial Z}{\partial u} & =0 .
\end{array}
$$

Let us find a vector product of the vectors (12):

$$
\begin{aligned}
& \left|\begin{array}{ccc}
X & Y & Z \\
-(R-u) \sin \alpha & (R-u) \cos \alpha & -R \operatorname{tg} \beta \\
-\cos \alpha & -\sin \alpha & 0
\end{array}\right|= \\
& =\{-R \operatorname{tg} \beta \sin \alpha ; \quad R \operatorname{tg} \beta \cos \alpha ; \quad R-u\} .
\end{aligned}
$$

The normal vector (13) is not a unit vector. Its position on the surface is determined by two internal coordinates $u$ and $\alpha$. It is necessary to know the normal to the surface of a screw on a helix at the point of particle location, that is to say, at $u=0$. Let us substitute $u=0$ into the vector equation (13) and reduce it to a unit one:

$$
\{-\sin \beta \sin \alpha ; \quad \sin \beta \cos \alpha ; \quad \cos \beta\} .
$$

Analogically, the normal to a cylindrical cover can be found. However, its projections can be found much easier. Figure 1, b shows that a normal to a cylinder is parallel to a horizontal plane and is directed toward its axis. Let us write the result:

$$
\{-\cos \alpha ; \quad-\sin \alpha ; \quad 0\} .
$$

For the foregoing reasons, let us rotate the unit vectors (14), (15) about the angle (- $-\omega t)$. After this, the unit normal vector to the surface of a screw at the point of particle location can be written as:

$$
\{\sin \beta \sin (\omega t-\alpha) ; \quad \sin \beta \cos (\omega t-\alpha) ; \quad \cos \beta\} .
$$

The unit normal vector to a cylindrical cover at the point of particle location takes the following form:

$$
\{-\cos (\omega t-\alpha) ; \quad \sin (\omega t-\alpha) ; \quad 0\} .
$$


The defined directions of the exerted forces are the following: for the friction forces $F_{f c}$ and $F_{f a}-$ by the unit vectors (6) and (11) taken opposite in sign; for the surface reactions $N$ of a screw and $N_{R}$ of a cylindrical cover - by the unit vectors (16) and (17), respectively. The last force - the force of particle weight $m g-$ is directed downwards, thus, the unit vector is set by the projections:

$$
\{0 ; \quad 0 ; \quad-1\} \text {. }
$$

The value of the friction forces $F_{f a}$ and $F_{f c}$ is determined by the value of surface reaction and the corresponding friction coefficient: $F_{f a}=f N, F_{f c}=f_{R} N_{R}$, where $f$ and $f_{R}$ - the coefficients of particle friction on the surface of a screw and on the surface of a cylindrical cover, respectively.

Let us break the vector equation $m \bar{a}=\bar{F}$ down in projections onto the axes of OXYZ coordinates, taking into consideration the directions (6), (11), (16), (17) and (18) of the corresponding forces $F_{f c}=f_{R} N_{R}$, $F_{f a}=f N, N, N_{R}$ and the weight force $m g$ :

$$
\begin{gathered}
m x_{a}^{\prime \prime}=f_{R} N_{R} \frac{\left(\omega-\alpha^{\prime}\right) \sin (\omega t-\alpha) \cos \beta}{\sqrt{\omega\left(\omega-2 \alpha^{\prime}\right) \cos ^{2} \beta+\alpha^{\prime 2}}}-f N \cos \beta \sin (\omega t-\alpha)+ \\
+N \sin \beta \sin (\omega t-\alpha)-N_{R} \cos (\omega t-\alpha) \\
m y_{a}^{\prime \prime}=f_{R} N_{R} \frac{\left(\omega-\alpha^{\prime}\right) \cos (\omega t-\alpha) \cos \beta}{\sqrt{\omega\left(\omega-2 \alpha^{\prime}\right) \cos ^{2} \beta+\alpha^{\prime 2}}}-f N \cos \beta \cos (\omega t-\alpha)+ \\
+N \sin \beta \cos (\omega t-\alpha)+N_{R} \sin (\omega t-\alpha) ; \\
m z_{a}^{\prime \prime}=f_{R} N_{R} \frac{\alpha^{\prime} \sin \beta}{\sqrt{\omega\left(\omega-2 \alpha^{\prime}\right) \cos ^{2} \beta+\alpha^{\prime 2}}}+f N \sin \beta+N \cos \beta-m g .
\end{gathered}
$$

Let us substitute the equations of absolute accelerations from (7) into (19) and we obtain the system of three differential equations with three unknown functions: $\alpha=\alpha(t), N=N(t)$ and $N_{R}=N_{R}(t)$. Let us solve the system of the equations for $\alpha^{\prime \prime}, N, N_{R}$ :

$$
\begin{gathered}
\alpha^{\prime \prime}=\frac{g \cos \beta}{R}(\sin \beta-f \cos \beta)+f_{R}\left(\omega-\alpha^{\prime}\right)^{2} \cos \beta \frac{\omega \cos \beta(\cos \beta+f \sin \beta)-\alpha^{\prime}}{\sqrt{\omega\left(\omega-2 \alpha^{\prime}\right) \cos ^{2} \beta+\alpha^{\prime 2}}} . \\
N=m \cos \beta\left(g-\frac{f_{R} R \omega\left(\omega-\alpha^{\prime}\right)^{2} \sin \beta}{\sqrt{\omega\left(\omega-2 \alpha^{\prime}\right) \cos ^{2} \beta+\alpha^{\prime 2}}}\right) . \\
N_{R}=m R\left(\omega-\alpha^{\prime}\right)^{2} .
\end{gathered}
$$

The differential equation (20) does not depend on (21) and (22), that is why it can be solved separately. The surface reactions (21) and (22) are found after the equation (20) is solved. In order to solve it, we need to apply numerical methods.

During its upward movement, a particle can move with various velocities. At the same angular velocity of screw rotation, the velocity of its upward movement $z_{a}^{\prime}$ will depend on the value of a helix angle $\beta$. After a transient process, that is to say, after the movement is stabilized, this velocity and the angular velocity of particle sliding $\alpha^{\prime}$ will be steady. Thus, the angular acceleration $\alpha^{\prime \prime}=0$. The substitution of this value into the differential equation (20) enables us to find the value of $\alpha^{\prime}$ at the preset screw parameters, the angular velocity of its rotation and friction coefficients.

\section{Results}

The investigation has been conducted for the cases of various values of the angle $\beta$. For example, at $\beta=10^{0}, R=0.1 \mathrm{~m}, \omega=15 \mathrm{~s}^{-1}, f=f_{R}=0.3$ we obtain $\alpha^{\prime}=2.1 \mathrm{~s}^{-1}$. At $\beta=20^{0}$ and when other parameters are constant, we obtain: $\alpha^{\prime}=-0.5 s^{-1}$. Thus, there is a change in the direction of particle sliding. It means that at $\beta=10^{0}$ a particle moves upwards (Fig. 2, a) and at $\beta=20^{0}$ it moves downwards (Fig. 2, b). At $\alpha^{\prime}=0$ a particle does not slide, that is to say, a particle «sticks» and rotates around a circle in absolute motion. In this case, it is necessary to find the corresponding helix angle $\beta$. Let us substitute $\alpha^{\prime}=0$ into the equation (20), equate it to zero and solve it for the angle $\beta$ :

$$
\beta=\operatorname{Arctg} \frac{R f_{R} \omega^{2}-f g}{R f_{R} f \omega^{2}+g} .
$$




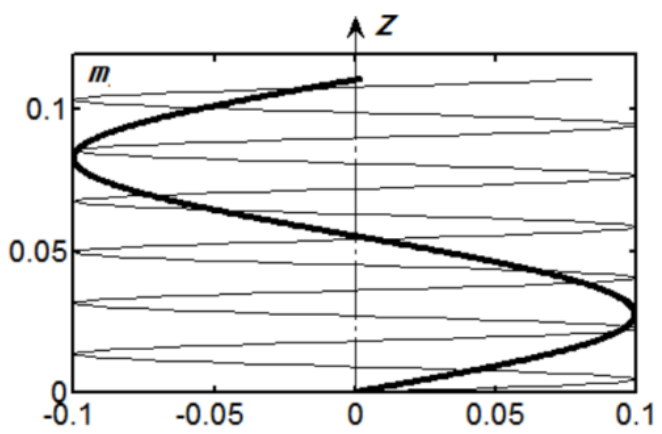

a)

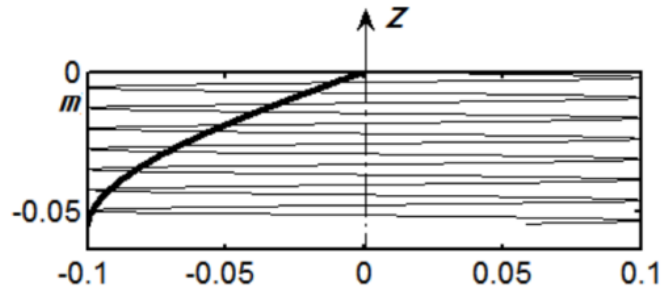

b)

Figure 2. Relative and absolute (heavy line) trajectories of particle movement at $R=0.1 \mathrm{~m}, \omega=15 \mathrm{~s}^{1}$, $f=f_{R}=0.3$ built according to the equations (1) and (3), at $\alpha=\alpha^{\prime} \cdot t$ over the time $t=3 \mathrm{~s}$ : a) $\beta=10^{0}$ - a particle moves upwards; b) $\beta=20^{0}-$ a particle moves downwards

According to (23), when $R=0.1 m, \omega=15 s^{-1}, f=f_{R}=0.3$, the boundary value of a helix angle is $\beta=17.8^{0}$. If $\beta \geq 17.8^{0}$, the upward movement of a particle at the preset parameters is not possible. If the angular velocity of screw rotation is increased, the boundary value of $\beta$ increases as well, but there is a certain limit. Let us find the boundary, which the expression (23) approaches to, at the unbounded increase of the angular velocity of rotation $\omega$ :

$$
\lim _{\omega \rightarrow \infty} \operatorname{Arctg} \frac{R f_{R} \omega^{2}-f g}{R f_{R} f \omega^{2}+g}=\operatorname{Arcctg} f .
$$

Arctg $f$ is the angle of particle friction on the surface of a screw and, in our case, it is equal to Arctg $0.3=16.7^{0}$. According to (24), the boundary value of the helix angle $\beta$ is Arcctg $0.3=73.3^{0}$, that is to say, these two angles add up to a right angle. At $\beta \geq 73.3^{0}$ particle upward movement is not possible for any angular velocities of screw rotation.

If a certain angular velocity $\omega$ of screw rotation is set, we can find the boundary value of a helix angle by the formula (23). In this range (from zero to the boundary value) there is a specific angle $\beta$, which provides the maximum velocity of particle upward transportation. The task is to determine the peak value of the last expression in the equations (4) or (8), since the vertical components of relative and absolute velocities are equal.

Since the equation (20) for a stationary process at $\alpha^{\prime \prime}=0$ must be solved by means of numerical methods in order to determine the value of the angular velocity $\alpha^{\prime}$ of particle sliding, the determination of the optimum angle $\beta$ will be carried out in two stages. At the first stage, from the equation (20) we evaluate $\alpha^{\prime}$ for the preset angles $\beta$ from the acceptable range of their values. At the second stage, by substituting the determined values of $\alpha^{\prime}$ and the corresponding angles $\beta$ into the last expression in the equations (4) or (8), we determine the vertical component of the velocity of a particle. According to these data, it is possible to plot a dependency graph $z^{\prime}=z^{\prime}(\beta)$, which determines the optimum value of the angle $\beta$. Let us present the simplified variant of the calculation for $\omega=15 s^{-1}$ (the acceptable range of the values of the angle $\beta=0 \ldots 17.8^{0}$ ):

$$
\begin{array}{lll}
\beta=5^{0} ; & \alpha^{\prime}=3.53 \mathrm{~s}^{-1} ; & z^{\prime}=0.03 \mathrm{~m} / \mathrm{s} ; \\
\beta=10^{0} ; & \alpha^{\prime}=2.08 \mathrm{~s}^{-1} ; & z^{\prime}=0.037 \mathrm{~m} / \mathrm{s} ; \\
\beta=15^{0} ; & \alpha^{\prime}=0.73 \mathrm{~s}^{-1} ; & z^{\prime}=0.02 \mathrm{~m} / \mathrm{s} .
\end{array}
$$

The obtained results show that the highest velocity of particle upward conveyance is provided by the angle $\beta=10^{\circ}$. According to the same method of calculation, let us find the optimum value of the angle $\beta$ for the angular velocity $\omega=25 \mathrm{~s}^{-1}: \beta=20^{0}$. Here, the vertical component of particle velocity is equal to $z^{\prime}=0.29 \mathrm{~m} / \mathrm{s}$. If we take into account that the acceptable range of the angle values for the velocity $\omega=25 \mathrm{~s}^{-1}$ is equal to $\beta=0 \ldots 45.7^{0}$, it may be concluded that the optimum value of the angle $\beta$ is close to the average value of the acceptable range. Paper [8] presents the formula for the determination of this angle in case when the angular velocity of screw rotation increases infinitely $(\omega \rightarrow \infty)$ :

$$
\beta=45^{0}-0.5 \operatorname{arctg} f .
$$


Let us find $\beta=36.65^{0}$ from (25) for $f=0$. This value is exactly two times less than the boundary one $\left(\beta=73.3^{0}\right)$, that is to say, it is precisely in the middle of the acceptable range.

Let us consider how the coefficients of friction $f$ and $f_{R}$ influence the velocity of particle upward movement. If there is a decrease in the coefficient $f$, the angular velocity $\alpha^{\prime}$ of particle sliding increases, that is to say, the velocity of its upward movement increases. The maximum value of the upward movement is reached at $f=0$, that is to say, when the surface of a screw is absolutely smooth. Figure 3, a presents a dependency graph $\alpha^{\prime}=\alpha^{\prime}(f)$ for $R=0.1 m, \omega=25 s^{-1}, f_{R}=0.3, \beta=20^{0}$.

The decrease of the coefficient $f_{R}$ of particle friction on a cylindrical cover results in the decrease in the angular velocity $\alpha^{\prime}$ of particle sliding (Fig. 3, b). The initial conditions are the same as the ones of the graph presented in Figure 3, a, except for the fact that the variable is not $f$ but $f_{R}$. Its decrease leads to the fact that, at its certain value the inverse process begins and a particle starts downward movement. The boundary limit is the value $f_{R}$ for $\alpha^{\prime}=0$. Having solved (23) for $f_{R}$, we obtain:

$$
f_{R}=\frac{g(f+\operatorname{tg} \beta)}{R \omega^{2}(1-f \operatorname{tg} \beta)} .
$$

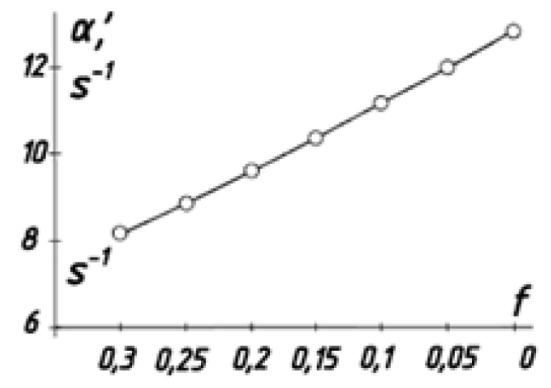

a) $R=0.1 m, f_{R}=0.3$

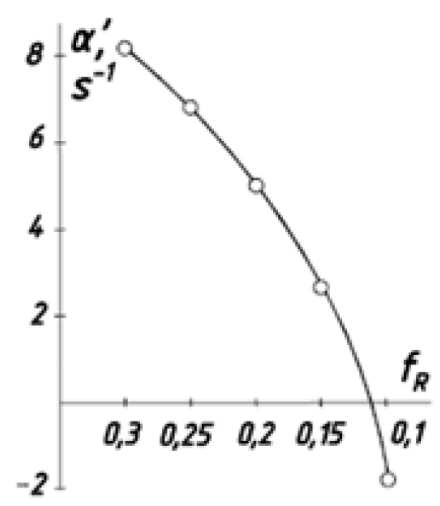

b) $R=0.1 m, f=0.3$;

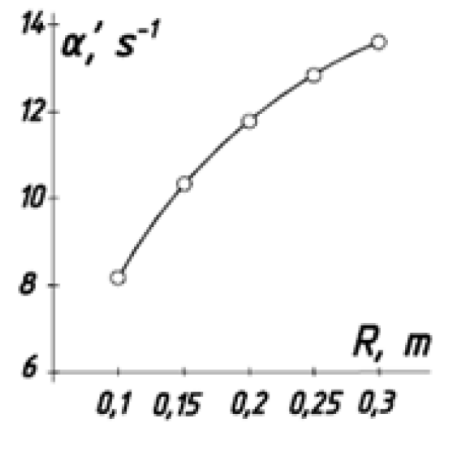

c) $f=0.3, f_{R}=0.3$

Figure 3. Graphs of the angular velocity of particle sliding $\alpha^{\prime}$ depending on various factors at $\omega=25 s^{-1}, \beta=20^{0}$

For the preset data from (26), we determine the boundary value of the friction coefficient $f_{R}: f_{R}=0.12$.

If the angular velocity of screw rotation is increased, for instance, to $30 \mathrm{~s}^{-1}$, particle upward movement is not possible. The boundary value of the coefficient of friction for this angular velocity is equal to $f_{R}=0.08$. If there is an increase in the angular velocity of screw rotation, the boundary value of the coefficient decreases. Proceeding to the boundary, we obtain:

$$
\lim _{\omega \rightarrow \infty} \frac{g(f+\operatorname{tg} \beta)}{R \omega^{2}(1-f \operatorname{tg} \beta)}=0
$$

Thus, if the surface of a cylindrical cover is absolutely smooth, particle upward movement is not possible at any angular velocities of screw rotation.

Figure 3, b presents a dependency graph $\alpha^{\prime}=\alpha^{\prime}(R)$ showing that the increase in the radius $R$, that is to say, the increase in the dimensions and the specific amount of metal per structure, results in the increase of the velocity of upward movement, however, this increase has its limit.

At the negative value of the angle $\beta$, the direction of the coiling of a helix changes. It means that at the same direction of the angular velocity of screw rotation, a particle slides not upwards but downwards on its surface. The transportation of a particle downwards has its peculiarities depending on the value of the angle $\beta$. If the sign is changed before the angle $\beta$ in the equation (20), one of the expressions in the parenthesis will be written as $f \cos \beta-\sin \beta$. If the angle $\beta$ is equal to the angle of friction, that is to say, $f=\operatorname{tg} \beta$, this expression becomes zero. In order for the equation (20) to become zero, it is enough to set one more expression in the parenthesis to zero: $\omega-\alpha^{\prime}=0$. It means that the angular velocity of particle sliding is equal in its value to the angular velocity of screw rotation. Since they are oppositely directed, their sum is equal to zero, that is to say, a particle does not rotate in absolute motion, it moves downwards along a straight line - a cylinder generator. 
Let us find $\alpha^{\prime}$ and $z^{\prime}$ for three angles: a small angle, a high angle and the angle that is equal to the friction angle $\beta_{f}$, the same as we did at particle upward movement for $R=0.1 \mathrm{~m}, \omega=15 \mathrm{~s}^{-1}, f=f_{R}=0.3$.

$$
\begin{array}{llrl}
\beta<\beta_{f}: & \beta=-10^{0} ; & \alpha^{\prime}=8.8 s^{-1} ; & z^{\prime}=-0.16 \mathrm{~m} / \mathrm{s} ; \\
\beta=\beta_{f}: & \beta=-\operatorname{Arctg} f=-16.7^{0} ; & \alpha^{\prime}=15 \mathrm{~s}^{-1} ; & z^{\prime}=-0.45 \mathrm{~m} / \mathrm{s} ; \\
\beta>\beta_{f}: & \beta=-20^{0} ; & \alpha^{\prime}=20.4 \mathrm{~s}^{-1} ; & z^{\prime}=-0.74 \mathrm{~m} / \mathrm{s} .
\end{array}
$$

Figure 4 presents relative and absolute trajectories of particle movement in these cases. Front projections are presented in various scales.

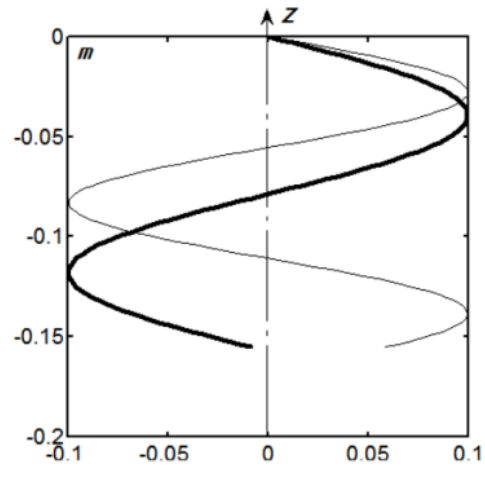

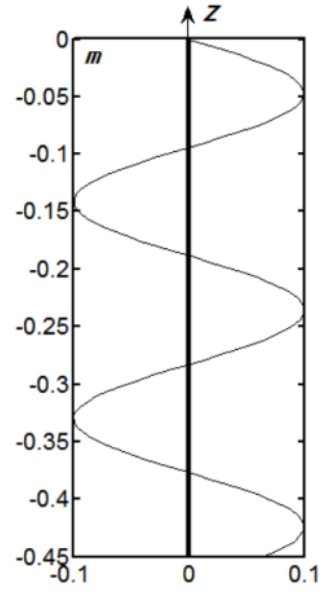

$\mathrm{b}$

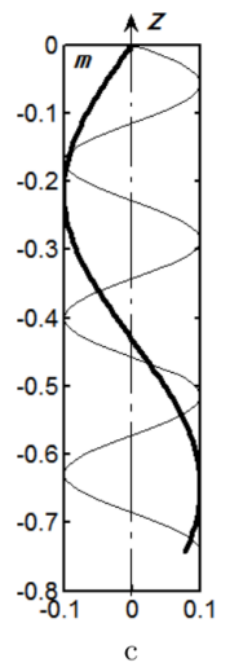

Figure 4. Relative and absolute (heavy line) trajectories of particle downward movement at $R=0.1 \mathrm{~m}$, $\omega=15 \mathrm{~s}^{-1}, f=f_{R}=0.3$ built according to the equations (1) and (3) over the time $t=1 \mathrm{~s}$

The solution of the differential equation (20) applying numerical methods enables us to determine the kinematic characteristics of particle movement during a transient process. Figure 5 presents the dependency graphs $\alpha^{\prime}=\alpha^{\prime}(t)$ and $z^{\prime}=z^{\prime}(t)$, which show that the movement of a particle becomes practically steady over the time of $1.5 \mathrm{~s}$. The angular velocities of particle sliding and the velocities of movement in a vertical direction reach the values that we have obtained before.

Eventually, the process of bulk material transportation will be different from the conveyance of a single particle.
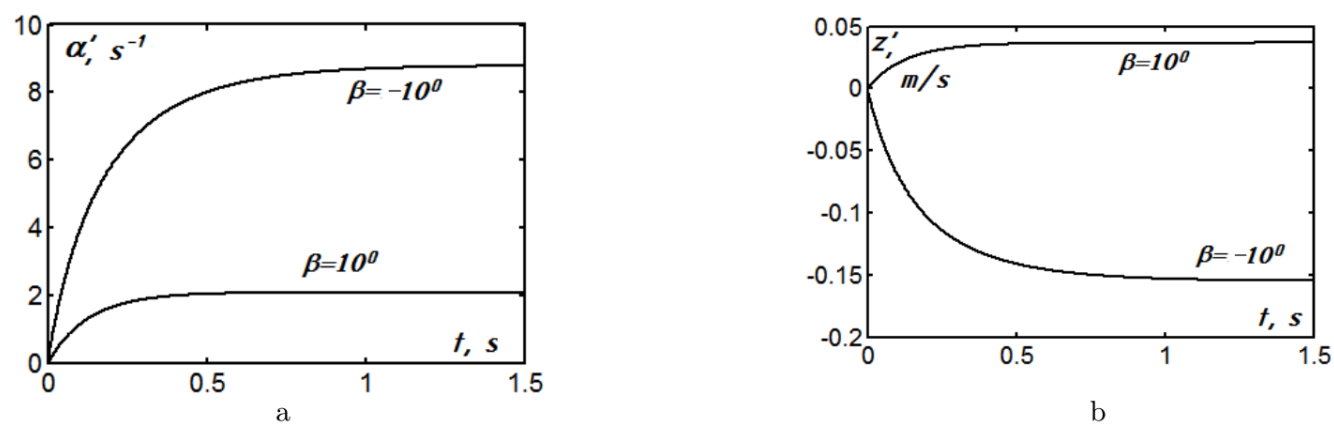

Figure 5. Graphs of the change of the kinematic characteristics of particle movement in a transient process at $R=0.1 \mathrm{~m}, \omega=15 \mathrm{~m}^{-1}, f=f_{R}=0.3$ and various values of the angle $\beta$ :

a) the dependency graph $\alpha^{\prime}=\alpha^{\prime}(t)$; b) the dependency graph $z^{\prime}=z^{\prime}(t)$ 
However, it can be assumed that the quality pattern of material transportation will be similar to the conveyance of a single particle. In order to determine quantitative characteristics, which describe the efficiency of conveyance, separate investigations are required.

\section{Conclusions}

A particle, which gets onto the surface of a vertical screw that rotates about its axis, is thrown off to a coaxial fixed limiting cylinder under the action of centrifugal force. Its further movement takes place along the common line of these two surfaces - a helix - with its simultaneous sliding on both surfaces. Particle absolute motion in a vertical direction can be both upward and downward, depending on the helix angle $\beta$ and on the angular velocity of screw rotation. There is a boundary value of the angle $\beta$, at which particle upward movement is not possible at any values of the angular velocity of screw rotation. In addition, there is the value of the angle, at which the velocity of upward movement is the highest.

The decrease in the coefficient of particle friction on the surface of a screw results in the increase of the velocity of its upward conveyance and the decrease in the coefficient of particle friction on the surface of a limiting cylinder results in the decrease of this velocity. If the surface of a screw is absolutely smooth, the velocity of particle upward movement is the highest and, if there is the same surface of a limiting cylinder, particle upward movement is not possible.

If there is a change in the coiling of a helix, particle conveyance is possible downwards only and the velocity is significantly higher.

\section{References}

1 Адамчук В.В. Дослідження відносного руху матеріальної частинки по похилій лопатці відцентрового апарата / В.В. Адамчук, В.М. Булгаков, С.Ф. Пилипака, Я. Франчак // Наук. вісн. Луган. нац. ун-ту. Технічні науки. - 2005. - № 29. - С. 32-56.

2 Адамчук В.В. Дослідження руху частинки по плоскому диску, який обертається навколо перпендикулярної осі, нахиленої до горизонту / В.В.Адамчук, В.М. Булгаков, Д.Г. Войтюк, С.Ф. Пилипака // Вісн. Львів. наці. аграр. ун-ту: агроінженерні дослідження. - 2008. - № 12 (2). - C. $189-197$.

3 Gevko R.B. The investigation of the process of a screw conveyer safety device actuation / R.B. Gevko, O.M. Klendiy // INMATEH: Agricultural Engineering. - 2014. - Vol. 42. - No. 1. - P. 55-60.

4 Гевко Р. Поектування пневмо-механічного транспортера сипких матеріалів / Р. Гевко, В. Дзюра, Р. Романовський // Вісн. Терноп. нац. техн. ун-ту. - 2009. - Т. 14. - № 4. - С. 84-88.

5 Hevko R.B. Mathematical model of the pneumatic-screw conveyor screw mechanism operation / R.B. Hevko, V.O. Dzyura, R.M. Romanovsky // INMATEH: Agricultural Engineering. - 2014. - Vol. 44. - No. 3. - P. 103-110.

6 Hevko R.B. Investigation of a transfer branch of a flexible screw conveyer / R.B. Hevko, M.B. Klendii, O.M. Klendii // INMATEH: Agricultural Engineering. - 2016. - Vol. 48. - No. 1. - P. 29-34.

7 Hevko R.B. Development of design and investigation of operation processes of loading pipes of screw conveyors / R.B. Hevko, R.I. Rozum, O.M. Klendii // INMATEH: Agricultural Engineering. - 2016. Vol. 50. - No. 3. - P. 89-96.

8 Hevko R.B. Feasibility study of the process of transpotration and stirring of mixture in continuous-flow conveyers / R.B. Hevko, B.O. Yazlyuk, M.V. Liubin, O.A. Tokarchuk, O.M. Klendii, V.R. Pankiv // INMATEH: Agricultural Engineering. - 2017. - Vol. 51. - No. 1. - P. 49-58.

9 Клендій М.Б. Розробка конструкції та обгрунтування параметрів лопатевого транспортера-змішувача / М.Б. Клендій // Наук. вісн. нац. аграр. ун-ту. - 2005. - Вип. 92. - С. 533-540.

10 Klendii M.B. Inverrelation between incidence ange and roll ange of concave disks of soil tillage implements / M.B. Klendii, O.M. Klendii // INMATEH: Agricultural Engineering. - 2016. - Vol. 49. — No. 2. P. $13-20$.

11 Klendii M.B. Analytical model of arranging soil-tilling concave disks for determination of geometrical and technical data / M.B. Klendii, S.F. Pylypaka // Науковий вісник НУБіП України. Техніка та енергетика АПК. - 2016. - № 241. - С. 140-150. 
12 Pylypaka S.F. Particle motion over the surface of a rotary vertical axis helicoid / S.F. Pylypaka, M.B. Klendii, O.M. Klendii // INMATEH: Agricultural Engineering. - 2017. — Vol. 51. - No. 1. P. $15-28$.

13 Пилипака С.Ф. Траєкторії руху частинок по шорсткій похилій площині при їх боковій подачі / С.Ф. Пилипака, А.В. Несвідомін // Прикладна геометрія та інженерна графіка. — 2011. - № 87. C. $36-41$.

14 Василенко П.М. Теория движения частицы по шероховатым поверхностям сельскохозяйственных машин / П.М. Василенко // Киев: УАСХН, 1960. - 283 с.

15 Вітровий А.О. Силовий аналіз робочого органу гнучкого гвинтового конвеєра / А.О. Вітровий, Р.Б. Гевко // Зб. наук. ст. Луцьк. державн. техн. ун-ту. Сільськогосподарські машини. - 1998. № 4. - C. 8-14.

16 Заика П.М. Избранные задачи земледельческой механіки / П.М. Заика. - Киев: УСХА, 1992. 507 c.

17 Hevko B.M. Improvement of machine safety devices / B.M. Hevko, R.B. Hevko, O.M. Klendii, M.V. Buriak, Y.V. Dzyadykevych, R.I. Rozum // Acta Polytechnica, Journal of Advanced Engineering. - 2018. Vol. 58. - No. 1. - P. 17-25.

18 Baranovsky V.M. Justification of rational parameters of a pneumoconveyor screw feeder / V.M. Baranovsky, R.B. Hevko, V.O. Dzyura, O.M. Klendii, M.B. Klendii, R.M. Romanovsky. // INMATEH: Agricultural Engineering. - 2018. - Vol. 54. - No. 1. - P. 15-24.

С.Ф. Пилипака, В.Н. Несвидомин, Н.Б. Клендий,

И.Л. Роговский, Т.А. Кресан, В.И. Троханяк

\title{
Бөлшектерді тік шнекпен, осьпен бірге шектелген қозғалмайтын цилиндрмен тасымалдау
}

\begin{abstract}
Бөлшектің тік шнектің шеткі бойынша салыстырмалы жылжуының дифференциалды теңдеулері құрастырылды, ол өз осінің айналасында айналатын және осьпен бірге қозғалмайтын цилиндрмен шектелген. Теңдеу сандық әдістермен есептелген және шнек беті мен шектеуші цилиндр үшін ортақ болып табылатын шнек жиегі - бұрандалы сызық бойынша бөлшектердің салыстырмалы қозғалысының траекториялары салынған. Шнек беті мен цилиндрлік қаптаманың беті бойынша бөлшектердің үйкеліс күші бөлек есепке алынған. Шнектің берілген бұрыштық жылдамдығы кезінде бөлшектердің көтерілуі мүмкін болмаған кезде бұрандалы желіні көтеру бұрышының шекті мәні табылды. Үйкеліс бұрыштарының және шектеуші цилиндр радиусының бөлшектердің көтеру жылдамдығына әсері анықталды. Уақыт функциясындағы кинематикалық сипаттамалардың графиктері келтірілген.
\end{abstract}

Kiлm сөздер: салыстырмалы қозғалыс, тік шнек, бөлшектер, бұрыштық айналу жылдамдығы, цилиндрлік қаптау, дифференциалдық теңдеулер, кинематикалық параметрлер.

С.Ф. Пилипака, В.Н. Несвидомин, Н.Б. Клендий,

И.Л. Роговский, Т.А. Кресан, В.И. Троханяк

\section{Транспортировка частицы вертикальным шнеком, ограниченным соосным неподвижным цилиндром}

Составлены дифференциальные уравнения относительного перемещения частицы по периферии вертикального шнека, который вращается вокруг своей оси и ограничен соосным неподвижным цилиндром. Уравнение рассчитано численными методами, и построены траектории относительного движения частицы по винтовой линии - кромке шнека, которая является общей для поверхности шнека и 
ограничивающего цилиндра. Отдельно учтена сила трения частицы по поверхности шнека и поверхности цилиндрического кожуха. Найдено пороговое значение угла подъема винтовой линии, когда подъем частицы становится невозможным при заданной угловой скорости вращения шнека. Выявлено влияние углов трения и радиуса ограничивающего цилиндра на скорость подъема частицы. Приведены графики кинематических характеристик в функции времени.

Ключевые слова: относительное движение, вертикальный шнек, частица, угловая скорость вращения, цилиндрический кожух, дифференциальные уравнения, кинематические параметры.

\section{References}

1 Adamchuk, V.V., Bulhakov, V.M., Pylypaka, S.F., \& Franchak, Yan. (2005). Doslidzhennia vidnosnoho rukhu materialnoi chastinki po pokhilii lopattsi vidtsentrovoho aparata [Investigation of relative material particle motion over an inclined blade of a centrifugal machine]. Naukovii visnik Luhanskoho natsionalnoho universitetu. Seriia Tekhnichni nauki - National Bulletin of Luhansk National University. Technical Sciences, LNAU, Vol. 29, 32-56 [in Ukrainian].

2 Adamchuk, V.V., Bulhakov, V.M., Voitiuk, D.H., \& Pylypaka, S.F. (2008). Doslidzhennia rukhu chastinki po ploskomu disku, iakii obertatsia navkolo perpendikuliarnoi osi, nakhilenoi do horizontu [Investigation of particle motion over a flat disk, which rotates about a perpendicular axis that is inclined to a horizon]. Visnik Lvivskoho natsionalnoho ahrarnoho universitetu: ahroinzhenerni doslidzhennia - Bulletin of Lviv National Agrarian University: agricultural engineering research. Lviv National Agrarian University, Vol. 12, 2, 189-197 [in Ukrainian].

3 Gevko, R.B., \& Klendiy, O.M. (2014). The investigation of the process of a screw conveyer safety device actuation. INMATEH: Agricultural Engineering, Vol. 42,1, 55-60.

4 Hevko, R.B., Dzyura, V.O., \& Romanovsky, R.M. (2009). Poektuvannia pnevmo-mekhanichnoho transportera sipkikh materialiv [Designing of pneumo-mechanical conveyer for loose materials]. Visnik Ternopilskoho natsionalnoho tekhnichnoho universitetu - Bulletin of I.Pyliui Ternopil State Technical University, Vol. 14, 4, 84-88 [in Ukrainian].

5 Hevko, R.B., Dzyura, V.O., \& Romanovsky, R.M. (2014). Mathematical model of the pneumatic-screw conveyor screw mechanism operation. INMATEH: Agricultural engineering, Vol. 44, 3, 103-110.

6 Hevko, R.B., Klendii, M.B., \& Klendii, O.M. (2016). Investigation of a transfer branch of a flexible screw conveyer. INMATEH: Agricultural engineering, Vol. 48, 1, 29-34.

7 Hevko, R.B., Rozum, R.I., \& Klendii, O.M. (2016). Development of design and investigation of operation processes of loading pipes of screw conveyors. INMATEH: Agricultural engineering, Vol. 50, 3, 89-96.

8 Hevko, R.B., Yazlyuk, B.O., Liubin, M.V., Tokarchuk, O.A., Klendii, O.M., \& Pankiv, V.R. (2017). Feasibility study of the process of transpotration and stirring of mixture in continuous-flow conveyers. INMATEH: Agricultural engineering, Vol. 51, 1, 49-58.

9 Klendii, M.B. (2005). Rozrobka konstruktsii ta obıruntuvannia parametriv lopatevoho transporterazmishuvacha [Design development and substantiation of the parameters of a bladed conveyer-mixer]. Naukovii visnik Natsionalnoho ahrarnoho universitetu - Scientific Bulletin of National Agrarian University, Vol. 92, 2, 533-540 [in Ukrainian].

10 Klendii, M.B., \& Klendii, O.M. (2016). Inverrelation between incidence ange and roll ange of concave disks of soil tillage implements. INMATEH: Agricultural Engineering, Vol. 49, 2, 13-20.

11 Klendii, M.B., \& Pylypaka, S.F. (2016). Analytical model of arranging soil-tilling concave disks for determination of geometrical and technical data. Naukovii visnik NUBiP Ukraini. Tekhnika ta energetika APK, Vol. 241, 140-150.

12 Pylypaka, S.F., Klendii, M.B., \& Klendii, O.M. (2017). Particle motion over the surface of a rotary vertical axis helicoids. INMATEH: Agricultural engineering, Vol. 51, 1, 15-28.

13 Pylypaka, S.F., \& Nesvidomin, A.V. (2011). Traektorii rukhu chastinok po shorstkii pokhilii ploshchini pri ikh bokovii podachi [Trajectories of particle motion over rough inclined planes at side feed]. Prikladna heometriia ta inzhenerna hrafika - Applied Geometry and Engineering Graphics, Vol. 87, 36-41 [in Ukrainian]. 
14 Vasilenko, P.M. (1960). Teoriia dvizheniia chastitsy po sherokhovatym poverkhnostiam selskokhoziaistvennykh mashin [Theory of particle motion over rough surfaces of agricultural machinery]. Kiev: UASKhN [in Russian].

15 Vitrovyi, A.O., \& Hevko, R.B. (1998). Silovii analiz robochoho orhanu hnuchkoho hvintovoho konveera [Power analysis of the operating element of a flexible screw conveyer]. Zbirnik naukovikh statei Lutskoho derzhavnoho tekhnichnoho universitetu silskohospodarski mashini-Collection of Scientific Papers Agricultural machinery, Vol. 4, 8-14 [in Ukrainian].

16 Zaika, P.M. (1992). Izbrannye zadachi zemledelcheskoi mekhaniki [Selected tasks of agricultural mechanics]. Kiev: USKhA [in Russian].

17 Hevko, B.M., Hevko, R.B., Klendii, O.M., Buriak, M.V., Dzyadykevych, Y.V., \& Rozum, R.I. (2018). Improvement of machine safety devices. Acta Polytechnica, Journal of Advanced Engineering, Vol. 58, 1, 17-25.

18 Baranovsky, V.M., Hevko, R.B., Dzyura, V.O., Klendii, O.M., Klendii, M.B., \& Romanovsky R.M. (2018). Justification of rational parameters of a pneumoconveyor screw feeder. INMATEH: Agricultural engineering, Vol. 54, 1, 15-24. 